\title{
РОЛЬ ТА ЗНАЧЕННЯ МЕДИЧНОЇ ЕВАКУАЦІЇ В СИСТЕМІ ЛІКУВАЛЬНО- ЕВАКУАЦІЙНИХ ЗАХОДІВ МЕДИЧНОГО ЗАБЕЗПЕЧЕННЯ ЗС УКРАЇНИ ПІД ЧАС АТО/ООС
}

\author{
І.П. Хоменко ${ }^{1}$, А.М. Галушка' ${ }^{1}$ В.О. Жаховський ${ }^{2}$, В.Г. Лівінський ${ }^{2}$ \\ ${ }^{1}$ Командування Медичних сил Збройних сил Украӥни (м. Київ) \\ гУкраїнська військово-медична академія (м. Київ)
}

Мета роботи - аналіз і узагальнення досвіду організації та проведення медичної евакуації поранених, уражених, травмованих і хворих (поранені) військовослужбовців в системі лікувальноевакуаційних заходів медичного забезпечення Збройних Сил (ЗС) України під час антитерористичної операції та операції Об'єднаних сил (АТО/OОC).

Матеріали та методи. Використані керівні документи з питань організації медичного забезпечення ЗС України та проведення медичної евакуації, періодичні військово-медичні видання, матеріали науково-практичних конференцій та щорічних зборів керівного складу медичної служби ЗС Украӥни. Методи дослідження: історичний, бібліографічний, системного підходу, статистичний, аналітичний, узагальнення.

Результати. У статті розглянуто організацію та проаналізовано досвід проведення медичної евакуації поранених військовослужбовців в системі лікувально-евакуаційних заходів медичного забезпечення ЗС України під час АТО/ООС. Наведено кількісні показники проведення медичної евакуації поранених по роках та видах ї̈ проведення (передова, тактична, стратегічна). Проведено порівняльний аналіз використання різних видів транспорту (повітряного, автомобільного, залізничного) залежно від видів медичної евакуації. Акцентовано увагу на необхідності більш широкого застосування авіаційного $i$ залізничного транспорту для проведення тактичної та стратегічної медичної евакуації.

Висновки. Медична евакуація є важливим елементом в системі лікувально-евакуаційних заходів медичного забезпечення ЗС України, завдяки якій реалізується один із основних принципів медичного забезпечення - своєчасність надання медичної допомоги. Ефективність медичної евакуації залежить від наявності достатньої кількості відповідних евакуаційно-транспортних підрозділів та санітарнотранспортних засобів, а також належної організації їх роботи. Досвід проведення медичної евакуації під час АТО/OОС підтвердив, що кожному етапу медичної евакуації притаманні свої особливості, що, відповідно, потребує різних видів санітарно-транспортних засобів для її проведення.

Ключові слова: медичне забезпечення, медична допомога, медична евакуація.

Вступ. Основою медичного забезпечення військ під час їх застосування $є$ система лікувально-евакуаційних заходів, яка являє собою сукупність взаємопов'язаних принципів організації надання медичної допомоги пораненим, ураженим, травмованим i хворим (поранені) військовослужбовцям, їх евакуації, лікування та реабілітації, а також призначених для цього сил і засобів медичної служби.

Завдяки медичній евакуації в умовах бойових дій реалізуються такі основні принципи медичного забезпечення як своєчасність та послідовність надання медичної допомоги пораненим i, як результат, - саме медична евакуація забезпечує ефективність всієї системи медичного забезпечення військ.

Вперше організація та порядок проведення медичної евакуації у Збройних Силах (3С) України були нормативно врегульовані у 2016 році, коли було затверджено Тимчасову настанову з медичної евакуації поранених і хворих у Збройних Силах України на особливий період [1].

У подальшому, відповідно до сучасних поглядів на форми і способи застосування військ (сил) в операціях (бойових діях) та організацію їх медичного забезпечення, a також $з$ урахуванням положень Принципів і політики медичного забезпечення НАТО (МС 0326/3), Спільної доктрини НАТО щодо медичного забезпечення (AJP-4.10(B), Спільної об'єднаної доктрини 3 медичної евакуації (STANAG 2546) та Доктрини медичного забезпечення Збройних Сил України було розроблено та введено в дію Керівництво з медичної евакуації у Збройних Силах України [2].

Медична евакуація - це комплекс організаційних, медичних і технічних заходів щодо виносу/вивозу поранених із поля бою та транспортування їх з одночасним медичним супроводом $з$ метою своєчасного і повного 
надання необхідної медичної допомоги та лікування [2]. На організацію проведення медичної евакуації впливають оперативна, бойова i медико-тактична обстановка, кліматичні та погодні умови, якість облаштування та протяжність шляхів евакуації.

Деякі питання організації та проведення медичної евакуації поранених в умовах бойових дій, у тому числі під час антитерористичної операції та операції Об'єднаних сил (АТО/ООС) вже досліджувалися та були оприлюднені у військово-медичних виданнях. Так, концептуальні засади організації та проведення медичної евакуації були сформульовані за участі авторів і реалізовані в керівних документах 3 питань медичної евакуації $[1,2,3]$. Питання управління медичною евакуацію в історичному аспекті та в сучасних умовах досліджували Галушка А.М. і співавтори [4]. Історичний досвід використання залізничного транспорту в попередніх війнах i перші спроби його використання під час антитерористичної операції (АTO) наводили Стриженко B.I. та співавтори $[5,6]$. Клінічні аспекти медичної евакуації та перший аналіз досвіду ії проведення під час АТО досліджували Король С.О., Верба А.В. і співавтори $[7,8]$. Водночас автори вперше аналізують i досліджують узагальнюючий досвід організації та проведення медичної евакуації поранених військовослужбовців за шість років АТО/OОС.

Мета роботи. Аналіз і узагальнення досвіду організації та проведення медичної евакуації поранених військовослужбовців в системі лікувально-евакуаційних заходів медичного забезпечення ЗС України під час ATO/OOC.

Об'єкт дослідження - система медичного забезпечення ЗС України.

Предмет дослідження - медична евакуація поранених військовослужбовців в системі лікувально-евакуаційних заходів медичного забезпечення ЗС України під час ATO/OOC.

Матеріали та методи. Використано керівні документи 3 питань організації медичного забезпечення ЗС України та проведення медичної евакуації, періодичні військово-медичні видання, матеріали науково-практичних конференцій та щорічних зборів керівного складу медичної служби ЗС України. Методи дослідження: історичний, бібліографічний, системного підходу, статистичний, аналітичний, узагальнення.

Результати та їх обговорення. Досвід медичного забезпечення ЗС України під час АTO/OOC на Сході України дозволив оцінити реальний стан та можливості військовомедичної служби у проведенні медичної евакуації в умовах бойових дій, у тому числі під час великих за кількістю та одночасно виникаючих санітарних втрат.

Аналізуючи ситуацію з наявністю сил $\mathrm{i}$ засобів для збору та евакуації поранених необхідно зазначити, що на початку АТО військові частини ЗС України взагалі не мали сил та засобів для вивезення/винесення поранених з поля бою, а саме: штатні ланки санітарів-носильників штатами не були передбачені; санітарні транспортери переднього краю, у тому числі броньовані, були відсутні.

Кількість санітарних автомобілів та автобусів для медичної евакуації у військових частинах була значно меншою від штатної потреби, значна кількість військових частин взагалі не мала санітарного транспорту, а наявний був представлений застарілими зразками радянських часів УАЗ-3962 і АС-66. Для проведення аеромедичної евакуації у ЗС України був літак «Віта», а для морської санітарний катер «Сокаль». Крім того, Національний військово-медичний клінічний центр «Головний військовий клінічний госпіталь» (НВМКЦ «ГВКГ») та військовомедичні клінічні центри (ВМКЦ) регіонів мали декілька санітарних автомобілів класу В та С.

Враховуючи визначення медичної евакуації, яка крім транспортування передбачає здійснення медичного супроводу поранених, слід зазначити, що крім евакотранспортних відділень медичних рот бригад, де були штатні посади санітарів, насамперед для завантаження тяжкопоранених в санітарний транспорт, у військових частинах та військово-медичних закладах, а також в автосанітарних ротах штатний медичний персонал для медичного супроводу поранених не був передбачений. 
Bce наведене дає підстави стверджувати, що медичні служби військових частин не були готовими до самостійного проведення медичної евакуації поранених із районів проведення АТО. За таких умов організувати їі проведення вдалося за рахунок залучення санітарного транспорту ВМКЦ і стаціонарних військових госпіталів (ВГ), а також транспорту волонтерів.

Загалом же військові частини, що виконували завдання в районах проведення АТО в період 2014-2018 років, постійно були недоукомплектованими санітарним транспортом, при цьому їх укомплектованість санітарним транспортом у 2014 році становила $55 \%$ від штатної потреби, броньованим санітарним транспортом - 2,6 \% від штатної потреби [9]. За час АТО/ООС (станом на кінець 2019 року) на оснащення медичної служби 3С України надійшли броньовані санітарні транспортери та сучасні санітарні автомобілі Богдан 2251, що дозволило забезпечити військові частини броньованим санітарним транспортом на $64 \%$, а санітарними автомобілями на $73 \%[10]$.

Управління медичною евакуацією в умовах АТО/OОС здійснювалося в загальній системі управління медичним забезпеченням 3С України по вертикалі від Військовомедичного департаменту Міністерства оборони України та Центрального військовомедичного управління Збройних Сил України (надалі вони трансформовані в Головне військово-медичне управління, а згодом - в Командування Медичних сил Збройних Сил України) через органи управління медичним забезпеченням АTO/OOC [11].

В межах проведення передової медичної евакуації винос/вивіз поранених із взводних, ротних опорних пунктів, блокпостів та медична евакуація 3 них і розгорнутих медичних пунктів військових частин здійснювалася до найближчих військових мобільних госпіталів (ВМГ) та визначених цивільних закладів охорони здоров'я (303), які утворювали I-й ешелон госпітальної допомоги, із залученням військової техніки та штатних санітарних автомобілів військових підрозділів, а також виділених у ї розпорядження санітарних автомобілів із складу окремих автосанітарних рот.
Для проведення тактичної медичної евакуації від ВМГ до 303 II-го ешелону госпітальної допомоги були встановлені шляхи медичної евакуації поранених військовослужбовців до ВМКЦ Північного регіону (м. Харків), 385 ВГ і обласної клінічної лікарні імені I.I. Мечнікова (м. Дніпро) та 450 ВГ (м. Запоріжжя), яка проводилася автомобільним, повітряним та залізничним транспортом.

Стратегічна медична евакуація передбачала подальшу евакуацію поранених військовослужбовців до 303 III-го ешелону госпітальної допомоги, а саме до НВМКЦ «ГВКГ» (м. Київ), ВМКЦ регіонів (м. Одеса, м. Вінниця та м. Львів), а також до та високоспеціалізованих клінічних установ Національної академії медичних наук України.

3 метою детального аналізу організації та проведення медичної евакуації наводимо її кількісні показники за 2016 рік - той період, коли їі порядок і зміст були визначені керівними документами, проведення було чітко організовано, а кількісні показники достовірними.

В межах проведення передової медичної евакуації всі поранені військовослужбовці доставлялися до ВМГ. У подальшому поранені, терміни лікування яких перевищували встановлені для ВМГ показники та не мали перспектив скорого повернення до військових частин, після надання їм встановленого виду та обсягу медичної допомоги підлягали подальшій медичній евакуації.

Кількісні показники тактичної та стратегічної медичної евакуації за 2016 рік наведено в таблиці 1. Загальна кількість евакуйованих із ВМГ (з І-го на II-й ешелон госпітальної допомоги) за 2016 рік становила 6995 осіб, у тому числі: поранені - 926 осіб; травмовані - 1477 осіб; соматичні хворі 4592 особи [12].

Медична евакуація здійснювалася вертольотами, санітарним автомобільним транспортом та залізничним транспортом шляхом виділення на безоплатній основі окремого відповідно обладнаного вагону у складі потягів «Інтерсіті» та «Експрес» від м. Красноармійськ до м. Дніпро, що дозволило скоротити ї̈ тривалість до 2-х годин. 
Кількість евакуйованих військовослужбовців у межах тактичної та стратегічної медичної евакуації (2016 рік)

\begin{tabular}{|l|c|c|c|c|}
\hline \multirow{2}{*}{ Вид санітарного транспорту } & \multicolumn{5}{|c|}{ Кількість евакуйованих } \\
\cline { 2 - 5 } & Поранені & Травмовані & Соматичні & Всього \\
\hline Тактична медична евакуація & \\
\hline Вертоліт & 342 & 256 & 441 & 1039 \\
\hline Автомобільний транспорт & 476 & 1004 & 3577 & 5057 \\
\hline Залізничний транспорт & 108 & 217 & 574 & 899 \\
\hline Загальна кількість евакуйованих & 926 & 1477 & 4592 & 6995 \\
\hline \multicolumn{7}{|c|}{ Стратегічна медична евакуація } \\
\hline Повітряний транспорт & 387 & 293 & 448 & 1128 \\
\hline Автомобільний транспорт & 23 & 33 & 197 & 253 \\
\hline Залізничний транспорт & 198 & 523 & 1722 & 2443 \\
\hline Загальна кількість евакуйованих & 608 & 849 & 2367 & 3824 \\
\hline
\end{tabular}

Загальна кількість евакуйованих із 303 II ешелону госпітальної допомоги до 303 III ешелону госпітальної допомоги (стратегічна медична евакуація) військовослужбовців за 2016 рік становила 3824 особи, у тому числі: поранені - 608 осіб; травмовані - 849 осіб; соматичні хворі 2367 осіб.

Таким чином, протягом 2016 року під час фази стабілізації збройного конфлікту, яка характеризувалася низькою інтенсивністю бойових дій з періодичними їх загостреннями, було проведено медичну евакуацію
10819 поранених військовослужбовців, у тому числі в межах тактичної медичної евакуації 6995 осіб (65\%), стратегічної медичної евакуації - 3824 осіб (35\%). Наведені дані свідчать про те, що майже половина поранених військовослужбовців - 3171 осіб (або $45 \%$ ) завершили лікування в 303, що розташовані в районах, наближених до проведення АТО.

Розподіл медичної евакуації поранених військовослужбовців у 2016 році за видами евакуації та санітарно-транспортними засобами наведено в таблиці 2.

Таблиця 2.

Розподіл медичної евакуації за видами евакуації та санітарно-транспортними засобами

\begin{tabular}{|c|c|c|c|c|c|c|}
\hline \multirow{4}{*}{$\begin{array}{c}\text { Види санітарно-транспортних } \\
\text { засобів }\end{array}$} & \multirow{2}{*}{\multicolumn{4}{|c|}{ Види евакуації }} & \multirow{3}{*}{\multicolumn{2}{|c|}{ Разом }} \\
\hline & & & & & & \\
\hline & \multicolumn{2}{|c|}{ Тактична } & \multicolumn{2}{|c|}{ Стратегічна } & & \\
\hline & абс.чис. & $\%$ & абс.чис. & $\%$ & абс.чис. & $\%$ \\
\hline Вертоліт, літак & 1039 & 14,9 & 1128 & 29,5 & 2167 & 20,0 \\
\hline Автомобільний транспорт & 5057 & 72,3 & 253 & 6,6 & 5310 & 49,1 \\
\hline Залізничний транспорт & 899 & 12,8 & 2443 & 63,9 & 3342 & 30,9 \\
\hline Всього & 6995 & 100 & 3824 & 100 & 10819 & 100 \\
\hline
\end{tabular}

За видами санітарного транспорту тактична медична евакуація поділилася таким чином: авіаційний транспорт (вертольоти) - 1039 осіб (15\%), автомобільний транспорт (санітарні автомобілі типу А та В) - 5057 осіб (72\%) та залізничний транспорт - 899 осіб (13\%). Значне перевищення використання автомобільного транспорту над залізничним на рівні тактичної евакуації $є$ закономірним та обгрунтованим, проте проведення медичної евакуації авіаційним транспортом лише $15 \%$ поранених на цьому рівні вважається недостатнім, що негативно впливає на своєчасність надання необхідної медичної допомоги.

Стратегічна медична евакуація за видами транспорту поділилася таким чином: авіаційний транспорт (літаки) - 1128 осіб (29,5\%), автомобільний транспорт (санітарні автомобілі типу В та С) - 253 особи (6,5\%) та залізничний транспорт - 2443 особи (64\%). 
Для цього виду медичної евакуації, що здійснюється на значні відстані, не характерно широке застосування автомобільного транспорту, перевага надається авіаційному та, особливо, залізничному транспорту.

Наведені показники свідчать, що кожному виду медичної евакуації (передова, тактична, стратегічна) притаманні свої особливості, що в свою чергу потребує різних видів санітарного-транспортних засобів для іiї проведення.

Перший реальний досвід застосування залізничного транспорту для медичної евакуації поранених військовослужбовців медична служба ЗС України отримала тільки під час АТO. Використання залізничного транспорту для медичної евакуації поранених під час АТО на Сході України у певні періоди стало вкрай необхідним, а на практиці виявилося доволі раціональним та ефективним і підтвердило його важливу роль та значення.
Iз загального числа евакуйованих протягом 2016 року поранених військовослужбовців $\quad$ (10819 осіб), урахуванням етапності надання медичної допомоги, евакуація залізничним транспортом була застосована у 3342 випадках, тобто в $30,9 \%$ всіх випадків медичної евакуації. Із загальної кількості евакуйованих залізничним транспортом тактична медична евакуація становить 899 випадків $(12,8 \%)$, стратегічна 2443 випадки (63,9\%).

Аеромедична евакуація здійснювалася повітряним транспортом (вертольотами МI-8 і санітарним літаком Ан-26 «Віта», а також транспортним літаком Ан-26). За 2014-2018 роки аеромедичну евакуацію літаками «Віта» та Ан-26 було проведено 5528 пораненим військовослужбовцям, у тому числі 3 підтримкою киснем - 370 пацієнтам, а на штучної вентиляції легень - 70 пацієнтам (табл. 3.) [13].

Таблиця 3.

Кількість поранених, травмованих і хворих, що були евакуйовані літаками «Віта» та Ан-26 (2014-2018 рр.)

\begin{tabular}{|c|c|c|c|c|c|c|c|c|}
\hline \multirow{2}{*}{ Рік } & \multicolumn{3}{|c|}{ Віта } & \multicolumn{3}{c|}{ Ан 26 } & \multicolumn{2}{|c|}{ Всього } \\
\cline { 2 - 9 } & $\begin{array}{c}\text { Кількість } \\
\text { вильотів }\end{array}$ & $\begin{array}{c}\text { Евакуйовано } \\
\text { поранених } \\
\text { хворих) }\end{array}$ & $\begin{array}{c}\text { н них } \\
\text { шВ }\end{array}$ & $\begin{array}{c}\text { Кількість } \\
\text { вильотів }\end{array}$ & $\begin{array}{c}\text { Евакуйовано } \\
\text { поранених } \\
\text { (хворих) }\end{array}$ & $\begin{array}{c}\text { них } \\
\text { на } \\
\text { ШВЛ }\end{array}$ & $\begin{array}{c}\text { Кількість } \\
\text { вильотів }\end{array}$ & $\begin{array}{c}\text { Евакуйовано } \\
\text { поранених } \\
\text { (хворих) }\end{array}$ \\
\hline 2014 & 128 & 1657 & 26 & 8 & 190 & - & 136 & 1847 \\
\hline 2015 & 56 & 1093 & 11 & 21 & 602 & - & 77 & 1695 \\
\hline 2016 & 71 & 925 & 9 & 4 & 82 & - & 75 & 1007 \\
\hline 2017 & 32 & 390 & 16 & 15 & 315 & 2 & 47 & 705 \\
\hline 2018 & 22 & 221 & 7 & 3 & 53 & 1 & 25 & 274 \\
\hline Всього & 309 & 4286 & 69 & 51 & 1242 & 3 & 350 & 5528 \\
\hline
\end{tabular}

Кількість поранених військовослужбовців, які потребували медичної евакуації у 2017 та 2018 роках, була дещо меншою, ніж у 2016 році (10819 осіб), i становила 6307 та 4766 осіб відповідно, у тому числі тактичної - 4299 (68,2\%) і 3504 (73,5\%) осіб та стратегічної - 2008 (31,8\%) та 1262 (26,5\%) осіб. У 2019 році загальна кількість евакуйованих зросла за рахунок збільшення кількості евакуйованих хворих на стратегічному рівні медичної евакуації (табл. 4) [10].

Наведені дані свідчать про те, що 3 року в рік зменшувалася кількість поранених військовослужбовців, які евакуюються для надання медичної допомоги як з рівня ВМГ, так і 3 II-го на III-й рівень надання госпітальної допомоги. Це стало можливим завдяки розширенню обсягу та поліпшення якості надання медичної допомоги у 303, наближених до районів бойових дій.

За видами санітарного транспорту у 2017-2018 роках тактична медична евакуація, у порівнянні 32016 роком, розподілилася таким чином:

2017 рік - авіаційний санітарний транспорт (вертольоти) - 1184 (27,5\%, збільшення на 12,5\%), автомобільний санітарний транспорт (санітарні автомобілі типу А та В) - 1154 (26,8 \%, зменшення майже 
в 3 рази) та залізничний транспорт - 1961 (45,7 \%, збільшення більш, ніж у 3 рази);

2018 рік у порівнянні з 2017 роком авіаційний санітарний

транспорт (вертольоти) - 676 (19,3\%, зменшення на
8,2\%), автомобільний санітарний транспорт (санітарні автомобілі типу А та В) - 1148 $(32,8 \%$, збільшення на $6,0 \%)$ та залізничний санітарний транспорт - 1680 (47,9\%, збільшення на 2,2 \%).

Таблиця 4.

Кількість евакуйованих військовослужбовців (тактична і стратегічна евакуація 2017-2019 рр.)

\begin{tabular}{|l|c|c|c|c|c|c|c|c|c|}
\hline \multirow{2}{*}{$\begin{array}{c}\text { Вид санітарного } \\
\text { транспорту }\end{array}$} & \multicolumn{9}{|c|}{ Пралкість евакуйованих } \\
\cline { 2 - 11 } & 2017 & 2018 & 2019 & 2017 & 2018 & 2019 & 2017 & 2018 & 2019 \\
\hline Тактична евакуація & 743 & 599 & 445 & 3556 & 2905 & 2421 & 4299 & 3504 & 2866 \\
\hline Стратегічна евакуація & 647 & 430 & 398 & 1361 & 832 & 2622 & 2008 & 1262 & 2720 \\
\hline $\begin{array}{l}\text { Загальна кількість } \\
\text { евакуйованих }\end{array}$ & 1390 & 1029 & 843 & 4917 & 4737 & 5043 & 6307 & 4766 & 5586 \\
\hline
\end{tabular}

Зазначені кількісні показники зміни структури тактичної медичної евакуації свідчать про зростання на цьому рівні ролі аеромедичної евакуації та евакуації залізничним транспортом, як таких, що забезпечують евакуацію поранених військовослужбовців у більш короткі терміни, що в свою чергу підвищує ефективність медичного забезпечення та, відповідно, покращує якість медичної допомоги.

Стратегічна медична евакуація у порівнянні 32016 роком за видами транспорту змінилася та поділилася по роках таким чином:

2017 рік - авіаційний транспорт (літаки) - 1033 (51,4 \%, збільшення майже в 2 рази), автомобільний транспорт (санітарні автомобілі типу В та С) - 163 (8,1 \%, майже на тому ж рівні, збільшення на 1,6\%) та залізничний транспорт - 812 (40,5\%, зменшення більш, ніж у півтора рази, з $64 \%$ ). Для цього виду медичної евакуації, що здійснюється на значні відстані, не характерно широке застосування автомобільного транспорту, проте зростає медична евакуації поранених, травмованих і хворих авіаційним транспортом, яка вже перевищила 50 \%, доля залізничного транспорт в структурі стратегічної медичної евакуації дещо знизилася;

2018 рік у порівнянні з 2017 роком авіаційний транспорт (літаки) - 684 (54,2\% зростання на 2,8 \%), автомобільний (санітарні автомобілі типу В та С) - 197 (15,6\%, збільшення майже в 2 рази) та залізничний 381 (30,2 \%, зменшення на 10,3 \%).

Наведені показники засвідчили подальше зростання ролі аеромедичної евакуації в структурі стратегічної медичної евакуації.

У 2019 році медична евакуація до ВМГ проводилася переважно санітарними автомобілями $(92,5 \%)$, реанімобілями $(5,2 \%)$ та вертольотами (2,3\%). 3 метою їі впорядкування до складу ВМГ були включені евакуаційні взводи, за рахунок особового складу та санітарних автомобілів яких сформовані евакуаційні екіпажі у складі фельдшера, бойового медика та водія.

Iз ВМГ на II рівень госпітальної допомоги санітарними автомобілями було евакуйовано $38,0 \%$ поранених військовослужбовців, реанімобілями - 1,1\%, вертольотами - 20,1\%, залізничним транспортом - 40,8 \%.

Показники стратегічної аеромедичної евакуації у 2019 році були меншими і за 50 літако-вильотів було евакуйовано 292 поранених, травмованих та хворих.

\section{Висновки}

1. Медична евакуація $€$ важливим елементом в системі лікувально-евакуаційних заходів медичного забезпечення ЗС України, завдяки якій забезпечується своєчасність надання медичної допомоги. В сучасних умовах застосування ЗС України, враховуючи тенденції подальшого розвитку системи 
медичного забезпечення військ 3 наближенням до стандартів НАТО, значення медичної евакуації тільки зростатиме.

2. Ефективність медичної евакуації залежить від наявності достатньої кількості відповідних евакуаційно-транспортних підрозділів та санітарно-транспортних засобів, а також належної організації їх роботи.

3. Досвід проведення медичної евакуації під час АТО/ООС підтвердив, що кожному етапу медичної евакуації притаманні свої особливості, що потребує різних видів санітарно-транспортних засобів для ï проведення. Відповідно до стандартів НАТО та досвіду організації й проведення медичної евакуації в передових країнах світу з метою

\section{Література}

1. Наказ Генерального штабу Збройних Сил України від 02.03.2016 року № 90 «Про затвердження Тимчасової настанови 3 медичної евакуації поранених і хворих у Збройних Силах України на особливий період».

2. Наказ Генерального штабу Збройних Сил України від 09.07.2018 року № 258 «Про затвердження Керівництва з медичної евакуації у Збройних Силах України».

3. Жаховський В.О. Роль та значення медичної евакуації в системі лікувально-евакуаційних заходів / В.О.Жаховський, В.Г. Лівінський // Військова медицина України. - Том 16 - 2.2016 C. 28-36.

4. Галушка А.М. Еволюція органів управління і координації медичної евакуації поранених і хворих / А.М. Галушка, А.П. Казмірчук, О.М. Власенко, В.І. Стриженко, О.Ю. Булах // Військова медицина України. - Том 16 - 4.2016 - С. 21-28.

5. Стриженко B.I. Історичний огляд еволюції застосування залізничних транспортних засобів для евакуації поранених і хворих / B.I. Стриженко, О.Ю. Булах, П.В. Мацера, 0.О. Ляшенко // Військова медицина України. - Том 17 - 1.2017 - С. 13-17.

6. Жаховський В.О. Використання залізничного транспорту для медичної евакуації поранених і хворих військовослужбовців / В.О.Жаховський, В.Г. Лівінський // Збірник наукових праць Національного ВМКЦ «ГВКГ» Сучасні аспекти військової медицини - К.2017. - Випуск 24. С. 3-17.

\section{References}

1. Nakaz Heneralnoho shtabu Zbroinykh Syl Ukrainy vid 02.03.2016 roku № 90 «Pro zatverdzhennia Tymchasovoi nastanovy z medychnoi evakuatsii poranenykh i khvorykh u Zbroinykh Sylakh Ukrainy na osoblyvyi period»[Order of the General забезпечення своєчасності надання медичної допомоги перевага надається аеромедичній евакуації.

4. В умовах обмежених можливостей застосування авіаційно-транспортних засобів зростає роль та значення залізничного транспорту для проведення як тактичної, так і стратегічної медичної евакуації. Використання залізничного санітарного транспорту під час застосування 3С України на території власної держави, за відсутності достатньої кількості авіаційного транспорту, $\epsilon$ найбільш доцільним та економічно вигідним способом проведення стратегічної медичної евакуації поранених військовослужбовців.

7. Король С.О. Особливості медичної евакуації поранених з вогнепальними та мінно-вибуховими пораненнями стопи під час антитерористичної операції (АТО) / С.О.Король // Військова медицина України. - Том 15 - 3.2015 - С. 37-41.

8. Верба А.В. Медична евакуація: її роль та значення в системі медичного забезпечення військ / А.В. Верба, О.М. Власенко, А.М. Галушка, В.О. Жаховський, В.Г. Лівінський // Військова медицина України. - Том 17 - 1.2017 - С. 5-13.

9. Досвід організації медичного забезпечення Збройних Сил України та інших військових формувань у ході антитерористичної операції. / Матеріали науково-практичної конференції 18 грудня 2014 року. - К: - 2014. - 108 с.

10. Матеріали зборів керівного складу медичної служби 3С України: Київ, 2020 р.- Командування Медичних сил Збройних Сил України.

11. Верба А.В. Медичне забезпечення Збройних Сил України: стан та погляди на перспективи розвитку / А.В.Верба, В.О.Жаховський, В.Г. Лівінський // Монографія. - К. : СПД Чалчинська Н.В., - 2017. - 420 с.

12. Матеріали зборів керівного складу медичної служби ЗС України: Київ, 2017 р.- Військовомедичний департамент Міністерства оборони України.

13. Матеріали зборів керівного складу медичної служби ЗС України: Київ, 2019 р.- Головне військово-медичне управління.

Staff of the Armed Forces of Ukraine dated 02.03.2016 № 90 «On approval of the Provisional Instruction on medical evacuation of the wounded and sick in the Armed Forces of Ukraine for a special period»]. 
2. Nakaz Heneralnoho shtabu Zbroinykh Syl Ukrainy vid 09.07.2018 roku № 258 «Pro zatverdzhennia Kerivnytstva z medychnoi evakuatsii u Zbroinykh Sylakh Ukrainy» [Order of the General Staff of the Armed Forces of Ukraine dated 9.07.2018 № 258 «On approval of the Manual on medical evacuation in the Armed Forces of Ukraine»].

3. Zhakhovskyi, V.O. Livinskyi, V.G. (2016). Rol ta znachennia medychnoi evakuatsii v systemi likuvalnoevakuatsiinykh zakhodiv Viyskova medicina Ukrainy. 16 (2). P. 28-36. [The role and significance of medical evacuation in the system of medical and evacuation measures]. Military Medicine of Ukraine. 2 (16). P. 2836.

4. Halushka, A.M. Evoliutsiia orhaniv upravlinnia i koordynatsii medychnoi evakuatsii poranenykh i khvorykh / A.M. Halushka, A.P. Kazmirchuk, O.M. Vlasenko, V.I. Stryzhenko, O.Iu. Bulakh // Viyskova medicina Ukrainy. - Tom 16 - 4.2016 - S. 2128. [Galushka A.N. Evolution of management and coordination of medical evacuation of the wounded and sick / A.N. Galushka, A.P. Kazmirchuk, O.N. Vlasenko, V.I. Strizhenko, O.Yu. Bulakh // Military Medicine of Ukraine. - Volume 16 - 4.2016 - P. 21-28].

5. Stryzhenko, V.I. Istorychnyi ohliad evoliutsii zastosuvannia zaliznychnykh transportnykh zasobiv dlia evakuatsii poranenykh i khvorykh / V.I. Stryzhenko, O.Iu. Bulakh, P.V. Matsera, O.O. Liashenko // Viyskova medycina Ukrainy. Tom 17 - 1.2017 - S. 13-17. [Strizhenko V.I. Historical review of the evolution of the use of railway vehicles for the evacuation of the wounded and sick / V.I. Strizhenko, O.Yu. Bulakh, P.V. Matsera, O.A. Lyashenko // Military Medicine of Ukraine. Volume 17 - 1.2017 - P. 13-17].

6. Zhakhovskyi, V.O. Vykorystannia zaliznychnoho transportu dlia medychnoi evakuatsii poranenykh i khvorykh viiskovosluzhbovtsiv / V.O. Zhakhovskyi, V.G. Livinskyi // Zbirnyk naukovykh prats Natsionalnoho VMKTs «GVKH» Suchasni aspekty viyskovoi mediciny - K.2017. - Vypusk 24. S. 3-17. [Zhakhovskyi V.A. The use of railway transport for the medical evacuation of wounded and sick servicemen / V.A. Zhakhovskyi, V.G. Livinsky // Collection of scientific works of the National VMCC «GVKG» Modern aspects of military medicine - K.2017. - Issue 24. P. 317].

7. Korol, S.O. Osoblyvosti medychnoi evakuatsii poranenykh $\mathrm{z}$ vohnepalnymy ta minno-vybukhovymy poranenniamy stopy pid chas antyterorystychnoi operatsii (ATO) // Viyskova medicina Ukrainy. Tom 15 - 3.2015 - S. 37-41. [Korol S.O. Peculiarities of medical evacuation of wounded with gunshot and mine explosions of foot during anti-terrorist operation (ATO) / S.O. Korol // Military Medicine of Ukraine. Volume 15 - 3.2015 - P. 37-41].

8. Verba, A.V., Vlasenko, O.M, Halushka, A.M., Zhakhovskyi, V.O., Livinskyi V.G. Medychna evakuatsiia: yii rol ta znachennia $\mathrm{v}$ systemi medychnoho zabezpechennia viisk Viyskova medicina Ukrainy. - Tom 17 - 1.2017 - S. 5-13. [Verba A.V. Vlasenko, O.N. Halushka, A.N. Zhakhovskyi, V.A. Livinsky V.G.Medical evacuation: its role and significance in the system of medical support of troops Military Medicine of Ukraine. - Volume 17 - 1.2017 P. 5-13].

9. Dosvid orhanizatsii medychnoho zabezpechennia Zbroinykh Syl Ukrainy ta inshykh viiskovykh formuvan $\mathrm{u}$ khodi antyterorystychnoi operatsii (2014) Materialy naukovo-praktychnoi konferentsii 18 hrudnia 2014 roku. K: 108. [Experience in organizing medical support of the Armed Forces of Ukraine and other military formations during the anti-terrorist operation. (2014) Proceedings of the scientific-practical conference on December 18, 2014. K: . $108 \mathrm{p}]$.

10. Materialy zboriv kerivnoho skladu medychnoi sluzhby ZS Ukrainy: Kyiv, 2020 r. - Komanduvannia Medychnykh syl Zbroinykh Syl Ukrainy. [Proceedings of the meeting of the management of the medical service of the Armed Forces of Ukraine: Kyiv, 2020 Medical Forces Command of the Armed Forces of Ukraine].

11. Verba, A.V., Zhakhovskyi, V.O., Livinskyi, V.G. Medychne zabezpechennia Zbroinykh Syl Ukrainy: stan ta pohliady na perspektyvy rozvytku / A.V. Verba, // Monohrafiia. - K. : SPD Chalchynska N.V., - 2017. 420 s. [Verba A.V. Medical support of the Armed Forces of Ukraine: state and views on the prospects of development. Monograph. K.: SPD Chalchynska N.V., 2017. -420 p].

12. Materialy zboriv kerivnoho skladu medychnoi sluzhby Zbroinykh Syl Ukrainy: Kyiv, 2017 r. Viiskovo-medychnyi departament Ministerstva oborony Ukrainy [Proceedings of the meeting of the management of the medical service of the Armed Forces of Ukraine: Kyiv, 2017 - Military Medical Department of the Ministry of Defense of Ukraine].

13. Materialy zboriv kerivnoho skladu medychnoi sluzhby ZS Ukrainy: Kyiv, 2019 r. - Holovne viyskovomedychne upravlinnia. [Proceedings of the meeting of the management of the medical service of the Armed Forces of Ukraine: Kyiv, 2019 - Main Military Medical Department]. 
РОЛЬ И ЗНАЧЕНИЕ МЕДИЦИНСКОЙ ЭВАКУАЦИИ В СИСТЕМЕ ЛЕЧЕБНО-ЭВАКУАЦИОННЫХ МЕРОПРИЯТИЙ МЕДИЦИНСКОГО ОБЕСПЕЧЕНИЯ ВС УКРАИНЫ ВО ВРЕМЯ АТО/ООС

\author{
И.П. Хоменко ${ }^{1}$ А.Н. Галушка'
}

${ }^{1}$ Командование Медицинских сил Вооруженных Сил Украины, г. Киев, Украина

гукраинская военно-медицинская академия, г. Киев, Украина

\begin{abstract}
Цель работы - анализ и обобщение опыта организации и осуществления медицинской эвакуации раненых, пораженных, травмированных и больных (раненные) военнослужащих в системе лечебноэвакуационных мероприятий медицинского обеспечения Вооруженных Сил (BC) Украины во время антитеррористической операции и операции Объединённых сил (АТО/ООС).
\end{abstract}

Материалы и методы. Использованы руководящие документы по вопросам медицинского обеспечения ВС Украины и проведения медицинской эвакуации, периодические военно-медицинские издания, материалы научно-практических конференций и ежегодных сборов руководящего состава медицинской службы ВС Украины. Методы исследования: исторический, библиографический, системного подхода, статистический, аналитический, обобщения.

Результаты. В статье рассмотрена организация и проанализирован опыт осуществления медицинской эвакуации раненых военнослужащих в системе медицинского обеспечения ВС Украины во время АТО/ООС. Приводятся количественные показатели проведенной медицинской эвакуации раненых по годам и видам её проведения (передовая, тактическая, стратегическая). Проведен сравнительный анализ использования разных видов транспорта (авиационного, автомобильного, железнодорожного) 8 зависимости от видов медицинской эвакуации. Акцентировано внимание на необходимости более широкого использования авиационного и железнодорожного транспорта для осуществления тактической и стратегической медицинской эвакуации.

Выводы. Медицинская эвакуация является важным элементом в системе лечебно-эвакуационных мероприятий медицинского обеспечения ВС Украины, благодаря которой реализуется один из главных принципов медицинского обеспечения - своевременность оказания медицинской помощи. Эффективность медицинской эвакуации зависит от наличия достаточного количества соответствующих эвакуационнотранспортных подразделений и санитарно-транспортных средств, а также правильной организации их работы. Опыт проведения медицинской эвакуации во время АТО/ООС подтверждает, что каждому этапу медицинской эвакуации присущи свои особенности, что, соответственно, создает потребность в разных видах санитарно-транспортных средств для её осуществления.

Ключевые слова: медицинское обеспечение, медицинская помощь, медицинская эвакуация.

\title{
THE ROLE AND SIGNIFICANCE OF MEDICAL EVACUATION IN THE SYSTEM OF MEDICAL EVACUATION MEASURES OF MEDICAL SUPPORT OF THE AF OF UKRAINE DURING ATO/JFO
}

\author{
I.P. Khomenko' ${ }^{1}$ A.M. Halushka1 ${ }^{1}$ V.O. Zhakhovsky², V.G. Livinskyi2 ${ }^{2}$ \\ ${ }^{1}$ Medical Forces Command of Armed forces of Ukraine, Kyiv, Ukraine \\ ${ }^{2}$ Ukrainian military medical academy, Kyiv, Ukraine
}

The purpose of the work is analysis and generalization of the experience of organizing and conducting medical evacuation of wounded, injured, injured and sick (wounded) military personnel in the system of medical evacuation measures for medical support of the Armed Forces of Ukraine during the anti-terrorist operation and the operation of the Joint Forces (ATO/JFO).

Materials and methods. Guidance documents on the medical support of the Armed Forces of Ukraine and the conduct of medical evacuation, periodic military medical publications, materials of scientific and practical conferences and annual fees of the senior staff of the medical service of the Armed Forces of Ukraine were used. Research methods: historical, bibliographic, systems approach, statistical, analytical, generalization.

Results. The article discusses the organization and analyzes the experience of medical evacuation of wounded soldiers in the medical support system of the Armed Forces of Ukraine during the ATO/JFO. Quantitative indicators of the medical evacuation of the wounded by years and types of its conduct (advanced, tactical, strategic) are given. A comparative analysis of the use of different types of transport (aviation, road, rail), depending on the types of medical evacuation. Attention is focused on the need for wider use of aviation and railway transport for tactical and strategic medical evacuation.

Conclusions. Medical evacuation is an important element in the system of medical evacuation measures for medical support of the Armed Forces of Ukraine, due to which one of the main principles of medical support is implemented - the timely provision of medical care. The effectiveness of medical evacuation depends on the availability of a sufficient number of appropriate evacuation and transport units and ambulance vehicles, as well as the proper organization of their work. The experience of medical evacuation during ATO/JFO confirms that each 
stage of medical evacuation has its own peculiarities, which, accordingly, creates the need for different types of sanitary vehicles for its implementation.

Key words: medical support, medical assistance, medical evacuation.

Конфлікт інтересів: відсутній.

Conflicts of interest: authors have no conflict of interest to declare.

\section{Відомості про авторів:}

Хоменко I.П. A,E,F - генерал-майор медичної служби, член-кореспондент НАМН України, доктор медичних наук, професор, командувач Медичних сил Збройних Сил України, Київ.

Галушка А.М. А,Е,F- полковник медичної служби, доктор медичних наук, професор, начальник штабу- заступник командувача Медичних сил Збройних Сил України, Київ.

Жаховський B.О. А,B,C,D,E - кандидат наук з державного управління, доцент, Науково-дослідний інститут проблем військової медицини Української військово-медичної академії, провідний науковий співробітник науково-дослідного відділу організації медичного забезпечення, Київ.

Лівінський В.Г. А,B,,D, - кандидат медичних наук, Науково-дослідний інститут проблем військової медицини Української військово-медичної академії, провідний науковий співробітник науково-дослідного відділу медичної стандартизації та метрологічного забезпечення, Київ.

$A$ - концепція та дизайн дослідження; $B$ - збір даних; $C$ - аналіз та інтерпретація даних;

$D$ - написання статті; $E$ - редагування статті; $F$ - остаточне затвердження статті.

\section{Сведения об авторах:}

Хоменко И.П. - генерал-майор медицинской службы, член-корреспондент НАМН Украины, доктор медицинских наук, профессор, командующий Медицинских сил Вооруженных Сил Украины, Киев.

Галушка А.М. - полковник медицинской службы, доктор медицинских наук, профессор, начальник штаба- заместитель командующего Медицинских сил Вооруженных Сил Украины, Киев.

Жаховский В.А. - кандидат наук государственного управления, доцент, Научно-исследовательский институт проблем военной медицины Украинской военно-медицинской академии, ведущий научный сотрудник научно-исследовательского отдела организации медицинского обеспечения, Киев.

Ливинский В.Г. - кандидат медицинских наук, Научно-исследовательский институт проблем военной медицины Украинской военно-медицинской академии, ведущий научный сотрудник научноисследовательского отдела медицинской стандартизации и метрологического обеспечения, Киев.

Information about authors:

Khomenko I.P. A, E, F - Major General MS, Corresponding Member of the National Academy of Medical Sciences of Ukraine, Doctor of Medical Sciences, Professor, Commander of the Medical Forces of the Armed Forces of Ukraine. https://orcid.org/0000-0002-8199-5083, Kyiv

Halushka A.M. A, E, F - Col. MS, Doctor of Medical Sciences, Professor, Chief of Staff - Deputy Commander of the Medical Forces of the Armed Forces of Ukraine. https://orcid.org/0000-0003-3530-0946, Kyiv

Zhakhovsky V.o. A,B,C,D,E - candidate of science in public administration, associate professor, Research Institute of Military Medicine of the Ukrainian Military Medical Academy, leading researcher of research department of medical support organization, Email:zhahovskiy-viktor@ukr.net, https://orcid.org/0000-00022665-2766, Kyiv

Livinskyi V.G.,A,C,D,- candidate of medical sciences, Research Institute of Military Medicine of the Ukrainian Military Medical Academy, leading researcher of the research department of medical standardization and metrological support, Email: v.livinskiy@gmail.com, https://orcid.org/0000-0002-1102-1128, Kyiv

$A$ - research concept and design; $B$ - collection and/or assembly of data; $C$ - data analysis and interpretation;

$D$ - writing the article; $E$ - critical revision of the article; $F$ - final approval of the article.

Адреса для листування: вул. Московська, 45/1, буд. 33, м. Київ 01015 